\title{
Melting glaciers: A probable source of DDT to the Antarctic marine ecosystem
}

HN Geisz

Virginia Institute of Marine Science

RM Dickhut

Virginia Institute of Marine Science

MA Cochran

Virginia Institute of Marine Science

WR Fraser

HW Ducklow

Follow this and additional works at: https://scholarworks.wm.edu/vimsarticles

Part of the Aquaculture and Fisheries Commons

\section{Recommended Citation}

Geisz, HN; Dickhut, RM; Cochran, MA; Fraser, WR; and Ducklow, HW, "Melting glaciers: A probable source of DDT to the Antarctic marine ecosystem" (2008). VIMS Articles. 984.

https://scholarworks.wm.edu/vimsarticles/984 
Melting Glaciers: A Probable Source of DDT to the Antarctic Marine Ecosystem

\author{
H E I D I N G E I S Z, * \\ REB EC C M . D I C KH U T, \\ M I CHELE A. COCHRAN, \\ WILLIAM R. FRASER, ${ }^{\dagger}$ A N D \\ H U G W . D U C K L O W \\ Virginia Institute of Marine Science, College of William and \\ Mary, Gloucester Point, Virginia 23062, Polar Oceans \\ Research Group, Sheridan, Montana 59749, and \\ Ecosystems Center, Marine Biological Laboratory, \\ Woods Hole, Massachusetts 02543
}

Received November 21, 2007. Revised manuscript received February 29, 2008. Accepted March 18, 2008.

Persistent organic pollutants reach polar regions by longrange atmospheric transport and biomagnify through the food web accumulating in higher trophic level predators. We analyzed Adélie penguin (Pygoscelis adeliae) samples collected from 2004 to 2006 to evaluate current levels of $\sum D D T$ ( $p, p^{\prime}-$ DDT $\left.+p, p^{\prime}-D D E\right)$ in these birds, which are confined to Antarctica. Ratios of $p, p^{\prime}$-DDT to $p, p^{\prime}-D D E$ in Adélie penguins have declined significantly since 1964 indicating current exposure to old rather than new sources of $\Sigma D D T$. However, DDDT has not declined in Adélie penguins from the Western Antarctic Peninsula for more than 30 years and the presence of $p, p^{\prime}$ DDT in these birds indicates that there is a current source of DDT to the Antarctic marine food web. DDT has been banned or severely restricted since peak use in the 1970s, implicating glacier meltwater as a likely source for DDT contamination in coastal Antarctic seas. Our estimates indicate that 1-4 $\mathrm{kg} \cdot \mathrm{y}^{-1} \Sigma \mathrm{DDT}$ are currently being released into coastal waters along the Western Antarctic Ice Sheet due to glacier ablation.

\section{Introduction}

Antarctica is often referred to as the last pristine environment (1); however, an increasing body of evidence suggests this is inaccurate. Circumpolar long-term research indicates that recent changes in the global climate, driven by anthropogenic influences, are particularly acute in Antarctica. For example, warming of the regional climate has been correlated with perturbations throughout the sea-ice dominated ecosystem along the Western Antarctic Peninsula (2). A lesser studied anthropogenic impact on the Antarctic ecosystem is the bioaccumulation and biomagnification of persistent organic pollutants (POPs) in apex predators.

Contaminants reach polar regions by long-range atmospheric transport where snow, ice, and associated microbial communities serve as conduits for introducing them into the marine ecosystem (3-5). Lipophilic POPs accumulate in fatty tissues of organisms and may biomagnify posing a risk

* Corresponding author phone: (804) 684-7474; fax: (804) 6847786; e-mail: heidig@vims.edu.

+ Polar Oceans Research Group, Sheridan, MT 59749.

‡ Ecosystems Center, Marine Biological Laboratory, Woods Hole, MA 02543. to higher trophic level organisms. Although adverse effects due to contaminant exposure have never been documented in Antarctic seabirds, long-term exposure in Arctic wildlife has shown physiological and population level effects such as immunosuppression, which increases the susceptibility of animals to infectious diseases (6). Additionally, Verreault et al. provide evidence linking organochlorine contamination in glaucous gulls (Larus hyperboreus) to a decrease in basal metabolic rate, which may have direct implications particularly for polar seabirds (7). Resident Antarctic seabirds, such as Adélie penguins, rely on fat stores to mitigate cold temperatures and seasonal decreases in food procurement or availability $(8,9)$. Therefore, physiological characteristics of survival in polar regions may increase the susceptibility of Antarctic penguins to contaminant loading and effects.

Adélie penguins are one of two truly Antarctic species of penguin foraging close to breeding colonies in the summer and following the sea-ice edge in the winter (9-12). The Antarctic food web is relatively short with the majority of higher trophic level organisms relying heavily on krill (Euphausia superba and E. crystallorophias). Restricted south of the Antarctic convergence, these birds provide an excellent species to examine baseline pollution levels and long-term trends of contaminants in the Southern Ocean ecosystem $(13-15)$.

DDT and its derivatives were first measured in Adélie penguins by Sladen et al. in 1964 (14), yet little is known about the long-term trends of contaminants like DDT in Antarctic populations. The objective of our study was to evaluate the current levels of $\sum D D T\left(p, p^{\prime}-D D T+p, p^{\prime}-D D E\right)$ in a resident Antarctic apex predator, the Adélie penguin. We hypothesized that as production and use of legacy POPs wanes, metabolic loss will exceed bioaccumulation in Antarctic seabirds. Therefore, $\Sigma$ DDT levels in Adélie penguin tissues will have declined with time unless there are "new" or continuing inputs of DDT to the Antarctic marine ecosystem.

\section{Experimental Section}

Study Sites. Collection of Adélie penguin (Pygoscelis adeliae) carcasses concentrated in two areas of the Antarctic: the Palmer Archipelago at $64^{\circ} 46^{\prime} \mathrm{S}, 64^{\circ} 03^{\prime} \mathrm{W}$ ( $n=8 ; 1$ male, 7 females) in 2004 and Cape Crozier, Ross Island at $77^{\circ} 26^{\prime} \mathrm{S}$, $169^{\circ} 12^{\prime} \mathrm{E}$ ( $n=5$; 2 males, 3 females) in 2006 (Figure 1). Additionally, addled and frozen eggs were collected from the Palmer area $(n=27)$ in 2004-2005 and Cape Royds, Ross Island at $77^{\circ} 33^{\prime} \mathrm{S}, 166^{\circ} 9^{\prime} \mathrm{E}(n=5)$ in 2006 .

Historical data were also collected at the following stations: the Palmer Archipelago at $64^{\circ} 46^{\prime} \mathrm{S}, 64^{\circ} 03^{\prime} \mathrm{W}$ (4), Cape Crozier, Ross Island at $77^{\circ} 26^{\prime} \mathrm{S}, 169^{\circ} 12^{\prime} \mathrm{E}$ (14), and Rumpa Island, Syowa Station, Japan at $69^{\circ} 00^{\prime} \mathrm{S}, 39^{\circ} 35^{\prime} \mathrm{E}$ (16), (Figure 1).

Sample Collection. Necropsy dissections were performed on carcasses collected under recovery permits (OPP NSF). All animals were collected post mortem, thus no animals were sacrificed for this project. From each bird, samples of subcutaneous fat were collected in lanced slices using acetone-cleaned stainless steel instruments. The samples were frozen at $-70^{\circ} \mathrm{C}$ in precombusted ( $4 \mathrm{~h} @ 400{ }^{\circ} \mathrm{C}$ ) jars until analysis.

Analysis. Tissues were analyzed for $\mathrm{p}, \mathrm{p}^{\prime}-$ DDT and its primary derivative $\mathrm{p}, \mathrm{p}^{\prime}$ - DDE. The analytical methods used were modifications of methods developed to measure pesticide residues in phytoplankton and krill (3). Given the high lipid content, egg yolk was analyzed when possible; otherwise, eggs were homogenized and subsampled. Though percent lipid was significantly higher in egg yolk than in 


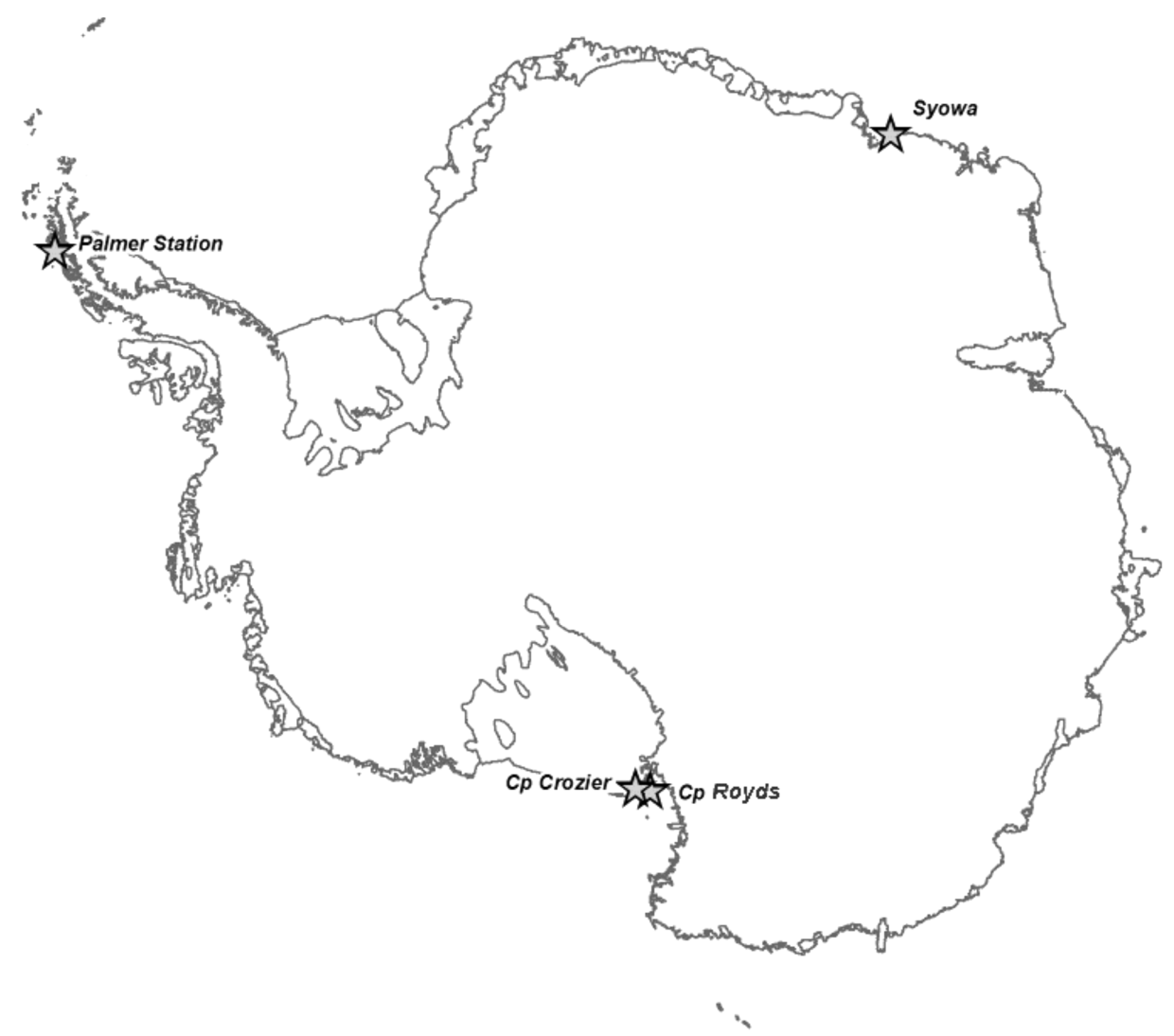

FIGURE 1. Historical and current study sites circumpolar to the Antarctic continent.

whole egg samples $(p=0.01), \mathrm{p}, \mathrm{p}^{\prime}$-DDE on a $\mathrm{ng} \cdot \mathrm{g}^{-1}$-lipid basis did not differ in the two tissue types $(p=0.38)$ showing no difference in the lipid storage capacity of these tissues. Fat ( $\sim 1-2$ g wet weight) and egg ( $\sim 3-5$ g wet weight) samples were homogenized, subsampled, and freeze-dried at $-80^{\circ} \mathrm{C}$ for $72 \mathrm{~h}$ using a Labconco Freezone 6 Plus. Each sample was thoroughly mixed with precombusted (4h @ $\left.400{ }^{\circ} \mathrm{C}\right)$ Varian Chem Tube-Hydromatrix to remove water. A surrogate standard containing deuterated $\alpha$-hexachlorocyclohexane $(\alpha$ $\mathrm{HCH}$ ) and 2,2',3,4,4',5,6,6'- octachlorobiphenyl (PCB-204, a noncommercially produced congener) was added. Samples were then extracted with $40 \mathrm{~mL}$ of pesticide-grade 65:35 (v/ v) dichloromethane (DCM)/acetone via accelerated solvent extraction (Dionex ASE 200 Accelerated Solvent Extractor: $1800 \mathrm{psi} ; 80^{\circ} \mathrm{C} ; 2$ cycles). The extracts were reduced in volume to $5 \mathrm{~mL}$ by turbo evaporation (Zymark Turbo Evap II) followed by blow down with ultrahigh purity $\mathrm{N}_{2}$.

Bulk lipid content was determined gravimetrically on each $5 \mathrm{~mL}$ sample extract in triplicate. Lipid content was calculated as the mass fraction of residue in a $20 \mu \mathrm{L}$ aliquot of the solvent extract after evaporation. Following bulk lipid analysis, the sample tubes were placed in an ice-water bath and $\mathrm{H}_{2} \mathrm{SO}_{4}$ was added dropwise to prevent heat buildup from the exothermic oxidation of the organic material, vortexed to remove lipids, and the hexane fraction was collected. Two additional hexane rinses $(\sim 3 \mathrm{~mL})$ were added to the acid/ lipid layer followed by vortexing and the combined hexane extracts were reduced under $\mathrm{N}_{2}$ to $3 \mathrm{~mL}$ and the acid extraction steps were repeated a second time. Further sample cleanup was performed by passing a final $1 \mathrm{~mL}$ extract through a column containing $8.5 \mathrm{~g}$ of precleaned (Soxhlet extracted with DCM for $24 \mathrm{~h}$ ) deactivated silica (mesh size 100-200) with $2 \mathrm{~g}$ of precleaned ( $4 \mathrm{~h} @ 400^{\circ} \mathrm{C}$ ) $\mathrm{Na}_{2} \mathrm{SO}_{4}$ added on top for removal of remaining undesired substances. Eluents of $25 \mathrm{~mL}$ of hexane, $50 \mathrm{~mL}$ of $40: 10(\mathrm{v} / \mathrm{v}) \mathrm{DCM} /$ hexane followed by an additional $25 \mathrm{~mL}$ of hexane were collected and reduced by turbo evaporation under $\mathrm{N}_{2}$ to 1
$\mathrm{mL}$. Deuterated lindane was added as an internal standard. Extracts were further blown down under $\mathrm{N}_{2}$ to $100 \mu \mathrm{L}$.

Samples were analyzed via gas chromatography/negative chemical ionization mass spectrometry (HewlettPackard 6890 Series GC system/Hewlett-Packard 5973 mass selective detector) using a J\&W DB-XLB narrow bore capillary column (30 m length, $0.25 \mathrm{~mm}$ diameter, $0.25 \mu \mathrm{m}$ film thickness) and selective ion monitoring. Method parameters for pesticide analysis were $50{ }^{\circ} \mathrm{C}$, initial hold time of $1 \mathrm{~min}$; $50-170{ }^{\circ} \mathrm{C} @ 20^{\circ} \mathrm{C} \mathrm{min}^{-1} ; 170-310^{\circ} \mathrm{C} @$ $5^{\circ} \mathrm{C} \mathrm{min}^{-1}$, hold for $5 \mathrm{~min}$; MS source temperature $150^{\circ} \mathrm{C}$; MS quad temperature of $130^{\circ} \mathrm{C}$. Helium was the carrier gas at $1.1 \mathrm{~mL} \mathrm{~min}^{-1}$ with a velocity of $39 \mathrm{~cm} \mathrm{~s}^{-1}$. Researchgrade methane was the reagent gas.

Targeted contaminants were quantified relative to the surrogate standards using peak areas and relative response factors generated by analysis of quantitative standards and reported per unit of lipid biomass $\left(\mathrm{ng} \cdot \mathrm{g}\right.$-lipid $\left.{ }^{-1}\right)$. Average DDT derivative concentrations in samples were compared to lipid-normalized laboratory blanks reporting only values that were $>3 \times$ blank quantities. $\Sigma$ DDT, primarily p, $\mathrm{p}^{\prime}$-DDE was detected in all samples analyzed (see Supporting Information). The method detection limits for $\mathrm{p}, \mathrm{p}^{\prime}$-DDT and p,p'-DDE were $1 \mathrm{ng} \cdot \mathrm{g}^{\prime}$ lipid $^{-1}$ and $8 \mathrm{ng} \cdot \mathrm{g}$-lipid ${ }^{-1}$, respectively, and surrogate standard recoveries averaged $63( \pm 13) \%$ and $81( \pm 22) \%$ for eggs and fat, respectively.

Data Analysis. To compare $\Sigma$ DDT in adult Adélie penguins, the mass weighted mean (MWM) of $\Sigma$ DDT in Adélie penguin fat for each study was calculated using (17):

$$
\operatorname{MWM}[C]=\frac{\sum_{i=1}^{n} M_{i}[C]_{i}}{\sum_{i=1}^{n} M_{i}}
$$

where $C=\ln (\Sigma \mathrm{DDT}), M_{i}$ is the mass (g) of bird specimen $i$, 
$[C]_{i}=\ln (\Sigma \mathrm{DDT})$ for bird $i$, and $n$ is the number of birds. The variance was calculated as follows (17):

$$
\operatorname{Var}(\mathrm{MWM})=\frac{n}{\left(\sum_{i=1}^{n} \mathrm{M}_{i}\right)^{2}} \times\left[\frac{n \sum_{i=1}^{n} \mathrm{M}_{i}^{2}[\mathrm{C}]_{i}^{2}-\left(\sum_{i=l}^{n} \mathrm{M}_{i}[\mathrm{C}]_{i}\right)^{2}}{n(n-1)}\right]
$$

Unpaired or paired (where appropriate) $t$ tests were performed to compare geometric means (eggs) or MWM (fat) values using Sigma Plot 9.0.

\section{Results and Discussion}

EDDT in Adélie Penguin Eggs. No p,p'-DDT was detected in any of the egg samples. The geometric mean concentration of p, $\mathrm{p}^{\prime}$-DDE in Adélie penguin eggs from the Palmer Archipelago was $170 \mathrm{ng} \cdot \mathrm{g}_{\text {-lipid }}{ }^{-1}($ range $=58.5-755 \mathrm{ng} \cdot \mathrm{g}$ lipid $^{-1}, n=17$ ) in 2004, and $177 \mathrm{ng} \cdot \mathrm{g}^{-l i p i d}{ }^{-1}$ (range $=$ 61.9-136 ng•g-lipid ${ }^{-1}, n=10$ ) in 2005. There was no significant difference ( $p=0.7, \mathrm{df}=25$ ), between $\mathrm{p}, \mathrm{p}^{\prime}$-DDE in Adélie penguin eggs collected in 2004 and 2005 from the Palmer area. The geometric mean concentration of $\mathrm{p}, \mathrm{p}^{\prime}$-DDE in Adélie penguin eggs from Cape Royds was $158 \mathrm{ng} \cdot \mathrm{g}^{-}$lipid $^{-1}$ (range $\left.=73.0-176 \mathrm{ng} \cdot \mathrm{g}_{\text {-lipid }}{ }^{-1}, n=17\right)$ in 2006, and there was no significant difference in $\mathrm{p}, \mathrm{p}^{\prime}$-DDE levels between the two collection locations of the current study ( $p=0.7, \mathrm{df}=$ $30)$.

A pooled comparison of the current Palmer geometric means (2004-2005) with data collected by Risebrough et al. (4) in 1970, 1974, and 1975 indicates that levels of p,p'-DDE, the primary and persistent metabolite of DDT, in Adélie penguin eggs from the Palmer area have not declined since 1970 ( $p=0.6$ ). However, Risebrough et al. (4) did not report sample recoveries rendering evaluation of the long-term change in $\mathrm{p}, \mathrm{p}^{\prime}$-DDE in Adélie penguin eggs questionable. A sensitivity analysis indicates that recoveries for this historical egg data would have to have been consistently $<53 \%$ for a significant decrease in p, p'-DDE in Adélie penguin eggs from 1970 to 2005 to be observed. However, an intercalibration study of International Decade of Ocean Exploration investigators, including Risebrough et al. (4), demonstrated that the accuracy of $\Sigma$ DDT (DDT + DDE + DDD) measurements ranged from 74 to $100 \%$ (18). Though p,p'-DDT was detected in penguin eggs during the 1970s the levels were reported to be only a small fraction of the concentration of $p, p^{\prime}-\mathrm{DDE}$ (4). Consequently, comparison of egg data from the present study to the data of Risebrough et al. (4) indicates that p, $\mathrm{p}^{\prime}$-DDE levels have not declined in the Palmer population of Adélie penguins in more than 30 years. In contrast, $\Sigma$ DDT decreased significantly from 1975 to 2003 in Arctic seabird eggs with half-lives of 9-20 years $(19,20)$. In the absence of current sources, $\Sigma$ DDT in penguin eggs would likewise decline.

¿DDT in Adélie Penguin Fat. In adult Adélie penguins, $75-90 \%$ of the $\Sigma$ DDT body burden is contained in subcutaneous fat and a time series analysis over a breeding season found that $\mathrm{DDDT}$ in penguin fat was significantly higher in fasting animals (16). Consequently, bird mass is found to be a significant predictor of $\Sigma$ DDT concentrations in Adélie penguins with $\Sigma$ DDT in penguins increasing as body weight declines (Figure 2). Therefore, we calculated mass weighted mean (MWM) concentrations for $\Sigma$ DDT in Adélie penguin fat samples in order to compare our results between sites and to previous studies.

The MWM of $\Sigma D D T$ in the fat of Adélie penguins from the Palmer Archipelago was $207 \mathrm{ng} \cdot \mathrm{g}^{-l_{i p i d}}{ }^{-1}$ (range $=105-312$ ng $\cdot$ g-lipid $^{-1}, n=8$; 1 male, 7 females), whereas the MWM of $\Sigma$ DDT in the fat of Adélie penguins from Cape Crozier was $262 \mathrm{ng} \cdot \mathrm{g}-\mathrm{lipid}^{-1}\left(\right.$ range $=101-450 \mathrm{ng} \cdot \mathrm{g}^{-\mathrm{lipid}^{-1},}, n=5 ; 2$

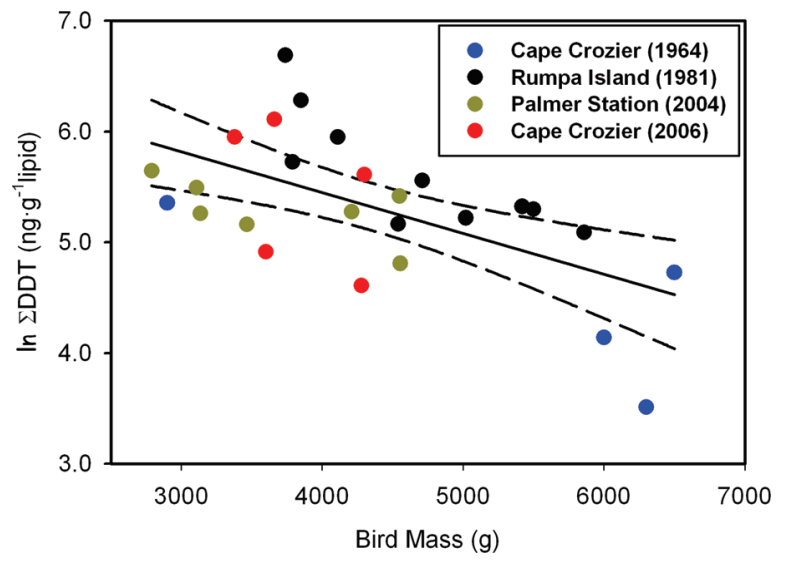

FIGURE 2. EDDT concentrations in Adélie penguins versus bird mass $\left(r^{2}=0.35 ; p=0.001\right)$. Cape Crozier 1964 data (14); Rumpa Island, Syowa Station 1981 data (16).

males, 3 females). Though female Adélies only lose $4 \%$ of total body burden of p,p'-DDE to egg laying each year (21), male and female Adélie penguins alternately fluctuate in body mass over a breeding season causing contaminant comparisons on a per lipid basis to show significant differences at specific instances during reproduction $(16,22)$. However, birds used in this study were integrated throughout the breeding season and comparative analyses of $\Sigma$ DDT MWM in penguin fat using pooled variance nonparametric statistics showed no significant difference $(p=0.08)$ between males and females in both this study and the study of Submaranian et al. (16) with $n=5$ males and $n=5$ females. Likewise, Adélies downed by trauma in the current study did not differ in $\Sigma$ DDT MWM from those that apparently died of slow starvation $(p=0.4)$.

The MWM of $\Sigma$ DDT in the fat of Adélie penguins from Cape Crozier measured in 2006 was significantly higher ( $p$ $<0.0005$ ) than that measured by Sladen et al. (14) in Adélie penguins from the same site in 1964. As noted above, sample recoveries were not reported in the previous studies $(4,14)$ rendering evaluation of changes in $\sum$ DDT in Adélie penguins with time questionable. However, the penguin samples collected in 1964 were analyzed in two separate laboratories using different methods to verify the results (14). The 1964 data, however, were not reported on a per lipid basis and were lipid normalized for the present analysis using a mean lipid fraction $(70( \pm 13 \%))$ calculated from the values in this study $(n=13)$ averaged with those from the literature $(n=$ 10 ; (16)). This normalization is conservative in that it increases the measured $\Sigma$ DDT reported on a wet weight basis (14) lessening the likelihood that the earlier data would be found to be significantly lower than the current $\Sigma$ DDT levels. As with the egg data, a sensitivity analysis indicates that recoveries for the historical data of Sladen et al. (14) would need to have been consistently $<24 \%$ for a significant decrease in $\Sigma$ DDT levels in Adélie penguin fat to have been observed between 1964 and 2006.

The observed increase in $\Sigma$ DDT in Adélie penguins from 1964 to 2006 is predicted using a steady-state bioaccumulation model. As applied to Adélie penguin tissues following large-scale global use of DDT beginning in 1947:

$$
\frac{d C_{\mathrm{ADPE}}}{d t}=k_{\mathrm{up}} C_{\mathrm{PREY}}-k_{\mathrm{elim}} C_{\mathrm{ADPE}}
$$

or

$$
C_{\mathrm{ADPE}}=\frac{k_{\mathrm{up}}}{k_{\text {elim }}} C_{\mathrm{PREY}}\left(1-\mathrm{e}^{-k_{\text {elim }} t}\right)
$$

where $C_{\mathrm{ADPE}}$ is $\Sigma \mathrm{DDT} \mathrm{MWM}$ concentration, $t$ is time (y), $k_{\mathrm{up}}$ 


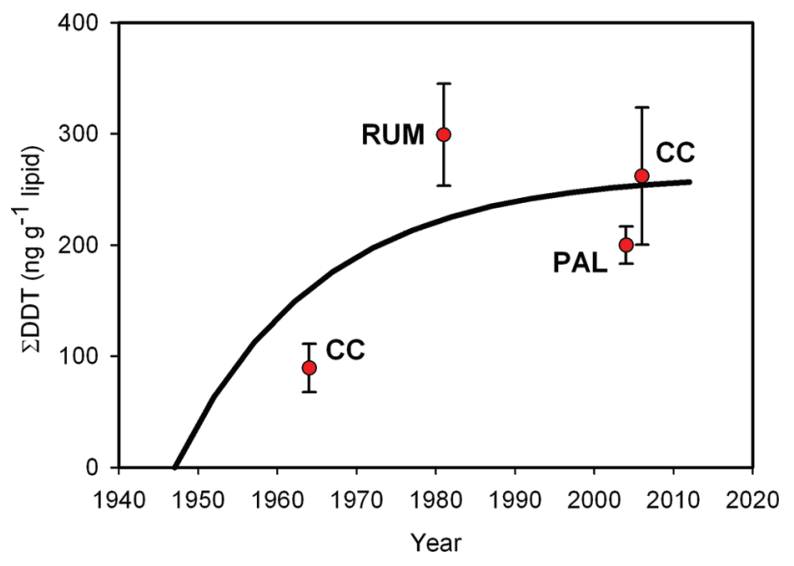

FIGURE 3. Changes in mass weighted mean (O) and predicted concentrations (curve) of XDDT in Adélie penguin subcutaneous fat from 1947 to 2010 . Predicted levels match measured values to within $10 \%$ for $2004-2006,34 \%$ in 1981 (16), and $44 \%$ in 1964 (14).

and $k_{\text {elim }}$ are the uptake and elimination rate constants, respectively, and $C_{\text {PREY }}$ is the concentration of $\Sigma$ DDT in penguin prey. Model values derived from the literature include $k_{\text {elim }}$, which is calculated as $0.055 \mathrm{y}^{-1}$, or the average elimination rate constant for $\Sigma$ DDT from three Arctic seabird species (thick-billed murre (Uria lomvia), northern fulmar (Fulmarus glacialis), and black-legged kittiwake (Rissa tridactyla) $)(19,20)$, and $C_{\mathrm{PREY}}=0.18 \mathrm{ng} \cdot \mathrm{g}$-lipid ${ }^{-1}$ as measured for E. superba (24). The uptake rate constant $\left(k_{\text {up }}\right)$ was calculated using eq 4 assuming that $\Sigma D D T$ in Adélie penguins is currently at steady state $\left(d C_{\mathrm{ADPE}} / d t=0\right)$ with $C_{\mathrm{ADPE}}=262$ $\mathrm{ng} \cdot \mathrm{g}$ lipid $^{-1}$ (MWM for 2006). The value for $C_{\mathrm{PREY}}$ applied to the model is limited to zooplankton, yet values for fish in the same ocean basin are on the same order of magnitude and model outputs including fish concentrations remain unchanged (24).

The model predictions match observed concentrations well (Figure 3), supporting the assumption of steady state levels for $\sum \mathrm{DDT}$ in Adélie penguins at present. This is consistent with the observation of no significant change in p,p'-DDE in Adélie penguin eggs at Palmer since 1970. Alternatively, LDDT concentrations in the Cape Crozier population of Adélie penguins may have peaked and subsequently declined between 1964 and 2006. However, there is no significant difference ( $p=0.18)$ between the MWM of $\sum$ DDT in Adélie penguins collected in 1981 from Synowa Station (Figure 1; (16)) and Cape Crozier Adélie penguins collected in 2006.

Cape Crozier Adélie penguins apparently feed at a higher trophic level than Palmer Adélie penguins $\left(\delta^{15} N=10.36\right.$ and 8.97, respectively; Geisz et al. unpublished) yet, there was no significant difference in $\mathrm{DDDT}$ MWM between populations $(p=0.1)$. Adélie penguins are a sea-ice dependent species that currently forage primarily on E. superba in the northwestern Antarctic peninsular region, yet around continental Antarctica, their diet is dominated by E. superba, E. crystallorophias, and a fish species, Pleuragramma antarcticum $(9-11,23)$. Therefore, the lack of a significant difference in SDDT in both eggs and fat of adult birds between the Palmer and Cape Crozier populations of Adélie penguins indicates that both populations accumulate similar levels of $\Sigma$ DDT even though the Palmer birds are feeding at a lower trophic level.

Finally, p,p'-DDT/p,p'-DDE ratios $<1.0$ for several Antarctic organisms, including Adélie penguin eggs, suggest contamination by old DDT (24). Indeed, the p, $\mathrm{p}^{\prime}$-DDT/p, $\mathrm{p}^{\prime}-$ DDE ratio measured in Adélie penguins has significantly declined since 1964 (Figure 4), indicating a predominance of old rather than new sources of $\Sigma$ DDT in the Antarctic

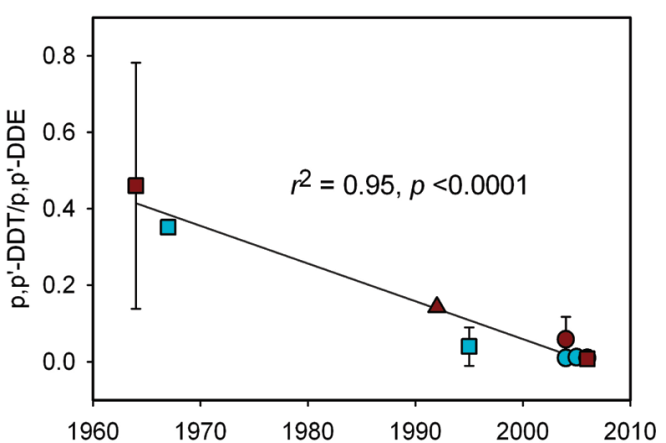

FIGURE 4. Ratio of $p, p^{\prime}-D D T / p, p^{\prime}-D D E( \pm S D)$ in Adélie penguin eggs and subcutaneous fat. Squares indicate the Ross Sea region $(14,24,32)$, circles represent data from the Palmer archipelago, and the triangle is Syowa (33). Dark red filled shapes show the ratio for subcutaneous fat and light blue indicates egg data. Ratio values for samples in which $p, p^{\prime}$-DDT was not detected were calculated using lipid corrected method detection limit values for $p, p^{\prime}-D D T$. Note that in 2006, the fat data point from the Ross Sea area overlays the egg data point.

marine food web. Nonetheless, $p, p^{\prime}$-DDT was detected in 7 of 8 birds from Palmer Station, but was not detected in any penguins collected from Cape Crozier. The presence of $p, p^{\prime}$ DDT in Palmer birds indicates exposure to a "fresh" source of DDT.

Glacier Melting as a Potential Source for DDDT to the Antarctic Marine Food Web. DDT has been banned in the northern hemisphere and regulated worldwide since the 1970s. Though DDT is still used in the Southern Hemisphere, current world usage is small $\left(\sim 1 \mathrm{kt} \cdot \mathrm{y}^{-1}\right)$ compared with historical use $\left(>40 \mathrm{kt} \cdot \mathrm{y}^{-1}\right)$ from 1950 to 1980 (25). Accordingly, a temporal analysis of eggs collected from three Arctic seabird species by Braune et al. $(19,20)$ found $\Sigma D D T$ residues in thick-billed murres, northern fulmars, and black-legged kittiwakes decreased significantly from 1975 to 2003 with half-lives of 20,13, and 9 years, respectively. Global use and emission of DDT have shown $>90 \%$ and $>80 \%$ decline since the late 1960s (25), yet in contrast to analogous Arctic species, इDDT levels in Adélie penguin eggs from the Palmer Archipelago reveal no change over the same time period. Though this is not necessarily surprising given the uninterrupted use of DDT in the Southern Hemisphere, air and water samples collected around Palmer Station in 2002 indicated there is very little recent DDT deposition in Antarctica, but measurable amounts of $\Sigma$ DDT in glacier meltwater in the area (3).

Both Arctic and Antarctic lake systems exhibit elevated contaminant levels where hydrology is heavily influenced by glacial runoff $(26,27)$. DDT and its derivatives, having relatively low volatility, partition onto the air-ice interface after snowfall, but sorb to organic material and particulates once the snow has melted (5). In 1975, $\Sigma$ DDT (90\% p, $\mathrm{p}^{\prime}$ DDT, $10 \%$ p, $\mathrm{p}^{\prime}$-DDE) was measured in snow down to $6 \mathrm{~m}$ below the surface on the Antarctic Peninsula (4). Using these data and a mean ice thickness of $1780 \mathrm{~m}$ (28), we estimate that $3.6 \mathrm{t}$ of $\sum \mathrm{DDT}$ may be stored in the Antarctic Peninsula ice sheet. In 2002, measurable levels of $\sum$ DDT with p,p'-DDT $>\mathrm{p}, \mathrm{p}^{\prime}$-DDE were found in glacier runoff and, more significantly, in near-shore plankton communities around Palmer Station (3).

The implication of glacier meltwater as a source mechanism for organic contaminant exposure to Antarctic organisms has compelling consequences in light of recent global climate change. Average annual winter temperature on the Antarctic Peninsula has increased $6{ }^{\circ} \mathrm{C}$ in the last 30 years (2), increasing the volume and frequency of glacier retreat and meltwater (29). In this region, there has been a transition from mean glacial growth $(62 \%$ advancing in 1954$)$ to retreat 
(87\% retreating in 2004) (29). Jacobs et al. (30) also report a patent decrease in salinity of the Ross Sea implicating, at least in part, melting of the Western Antarctic Ice Sheet (WAIS) as a causal mechanism. A 1998 mass balance also demonstrated net loss of ice over the entire West Antarctic Ice Sheet, $\left(210 \mathrm{Gt} \cdot \mathrm{y}^{-1} ;(31)\right)$. Snow collected in 1975 along the Western Antarctic Peninsula contained $\sim 8130 \mathrm{ng} \cdot \mathrm{m}^{-2} \Sigma \mathrm{DDT}(4)$, combined with a mean ice thickness of $1780 \mathrm{~m}$ (28) and net loss of ice of $210 \mathrm{Gt} \cdot \mathrm{y}^{-1}$ (31) these data yield a $\mathrm{EDDT}$ flux of $\sim 1 \mathrm{~kg} \cdot \mathrm{y}^{-1}$ to Antarctic coastal waters. Glacier meltwater collected in 2002 near Palmer Station contained $0.0187 \mathrm{ng} \cdot \mathrm{L}^{-1}$ $\Sigma$ DDT (3), which translates to a $\Sigma$ DDT flux of $\sim 4 \mathrm{~kg} \cdot \mathrm{y}^{-1}$ with $210 \mathrm{Gt} \cdot \mathrm{y}^{-1}$ ice lost (31). Thus, two independent measurements of $\Sigma$ DDT indicate that $1-4 \mathrm{~kg} \cdot \mathrm{y}^{-1} \Sigma \mathrm{DDT}$ is currently being released into the Antarctic marine environment due to glacier ablation. Our findings reveal an unexpected consequence of climate change and implicate glacier meltwater as a current source of $\Sigma$ DDT to the Antarctic marine food web.

\section{Acknowledgments}

Supported by NSF OPP0217282 to H.D. (Palmer Long Term Ecological Research project) and by the United States Environmental Protection Agency (EPA) under the Science to Achieve Results (STAR) Graduate Fellowship Program. This publication is not officially endorsed by EPA and may not reflect the views of the agency. We thank the scientists and support staff at Palmer and McMurdo Research Stations, specifically S.D. Emslie, D.G. Ainley, G. Ballard, and V. Toniolo. VIMS Contribution No. 2923. Palmer LTER Contribution No. 0302.

\section{Supporting Information Available}

Tables of the data used in the current study. This information is available free of charge via the Internet at http:// pubs.acs.org.

\section{Literature Cited}

(1) Ainley, D. Insights from study of the last intact neritic marine ecosystem. Trend Ecol. Evolution 2007, 22, 444

(2) Ducklow, H. W.; Baker, K.; Martinson, D. G.; Quetin, L. B.; Ross, R. M.; Smith, R. C.; Stammerjohn, S. E.; Vernet, M.; Fraser, W. Marine pelagic ecosystems: the West Antarctic Peninsula. Philos. Trans. R. Soc., B 2007, 362, 67-94.

(3) Chiuchiolo, A. L.; Dickhut, R. M.; Cochran, M. A.; Ducklow, H. W. Persistent organic pollutants at the base of the Antarctic marine food web. Environ. Sci. Technol. 2004, 38, 3551-3557.

(4) Risebrough, R. W.; Walker, W., II; Schmidt, T. T.; de Lappe, B. W.; Connors, C. W. Transfer of chlorinated biphenyls to Antarctica. Nature 1976, 264, 738-739.

(5) Wania, F. Modeling the fate of non-polar organic chemicals in an ageing snow pack. Chemosphere 1997, 35 (10), 2345-2363.

(6) Fisk, A. T.; de Wit, C. A.; Wayland, M.; Kuzyk, Z. Z.; Burgess, N.; Letcher, R.; Braune, B.; Norstrom, R.; Polischuk Blum, S.; Sandau, C.; Lie, E.; Larsen, H. J. S.; Skaare, J. U.; Muir, D. C. G. An assessment of the toxicological significance of anthropogenic contaminants in Canadian arctic wildlife. Sci. Total Environ. 2005, 351-352, 57-93.

(7) Verreault, J.; Bech, C.; Letcher, R. J.; Robstad, E.; Dahl, E.; Gabrielsen, G. W. Organohalogen contamination in breeding glaucous gulls form the Norwegian Arctic: Associations with basal metabolism and circulating thyroid hormones. Environ. Pollut. 2007, 145, 138-145.

(8) Johnson, S. R.; West, G. C. Fat content, fatty acid composition and estimates of energy metabolism of Adélie penguins ( $P y$ goscelis adeliae) during the early breeding season fast. J Comp. Biochem. Physiol., B 1973, 45, 709-719.

(9) Ainley, D.; deLeiris, L. The Adélie Penguin:Bellweather of Climate Change; Columbia University Press, 2002.

(10) Volkman, N. J.; Presler, P.; Trivelpiece, W. Diets of pygoscelid penguins at King George Island, Antarctica. Condor 1980, 82, 372-378.

(11) Fraser, W. R.; Trivelpiece, W. Z. Factors controlling the distribution of seabirds: winter-summer heterogeneity in the distribu- tion of Adélie penguin populations. Found. Ecol. Res. West Antarctic Peninsula, Antarctic Res. Ser. 1996, 70, 257-272.

(12) Fraser, W. R.; Hofmann, E. E. A predator's perspective on causal links between climate change, physical forcing and ecosystem response. Mar. Ecol.: Prog. Ser. 2003, 265, 1-15.

(13) Van den Brink, N. W. Probing for the invisible. Ph. D. dissertation, 1997, Groningen University, Wageningen, Netherlands.

(14) Sladen, W. J. L.; Menzie, C. M.; Reichel, W. L. DDT residues in Adélie penguins and a crabeater seal from Antarctica. Nature 1966, 210, 670-673.

(15) Van den Brink, N. W. Directed transport of volatile organochlorine pollutants to polar regions: the effect on the contamination pattern of Antarctic seabirds. Sci. Total Environ. 1997, 198, 4350.

(16) Subramanian, B. R.; Tanabe, S.; Tanaka, H.; Hidaka, H.; Tatsukawa, R. Bioaccumulation of organochlorines (PCBs and p,p'-DDE) in Antarctic Adélie penguins Pygoscelis adeliae collected during a breeding season. Environ. Pollut. 1986, 40, 173-189.

(17) Galloway, J. N.; Likens, G. E.; Hawley, M. E. Acid precipitation: natural versus anthropogenic components. Science 1984, 226, 829-831.

(18) Harvey, G. R.; Milkas, H. P.; Bowen, V. T.; Steinhauer, W. G. Observations on the distribution of chlorinated hydrocarbons in Atlantic Ocean organisms. J. Mar. Res. 1974, 32, 103.

(19) Braune, B. M.; Donaldson, G. M.; Hobson, K. A. Contaminant residues in seabird eggs from the Canadian Arctic. Part I. Temporal trends 1975-1998. Environ. Pollut. 2001, 114, 39-54.

(20) Braune, B. M. Temporal trends of organochlorines and mercury in seabird egg from the Canadian Arctic, 1975-2003. Environ. Pollut. 2007, 148, 599-613.

(21) Tanabe, S.; Subramanian, A. N.; Hidaka, H.; Tatsukawa, R. Transfer rates and pattern of PCB isomers and congeners and p, p'-DDE from mother to egg in Adélie penguin (Pygoscelis adeliae). Chemosphere 1986, 15, 343-351.

(22) Van den Brink, N. W.; Van Franeker, J. A.; de Ruiter-Dukman, E. M. Fluctuating concentrations of organochlorine pollutants during a breeding season in two Antarctic seabirds: Adélie Penguin and Southern Fulmar. Environ. Toxicol. Chem. 1998, 17, 702-709.

(23) Fraser, W. R.; Trivelpiece, W. Z.; Ainley, D. G.; Trivelpiece, S. G. Increases in Antarctic penguin populations: reduced competition with whales or a loss of sea ice due to environmental warming. Polar Biol. 1992, 11, 525.

(24) Corsolini, S.; Covaci, A.; Ademollo, N.; Focardi, S.; Schepens, P. Occurrence of organochlorine pesticides (OCPs) and their enantiomeric signatures, and concentrations of polybrominanted diphenyl ether (PBDEs) in the Adélie penguin food web, Antarctica. Environ. Pollut. 2006, 140, 371-382.

(25) Li, Y. F.; Macdonald, R. W. Sources and pathways of selected organochlorine pesticides to the Arctic and the effect of pathway divergence on $\mathrm{HCH}$ trends in biota: a review. Sci. Total Environ. 2005, 342, 87-106.

(26) Blais, J. M.; Schindler, D. W.; Muir, D. C. G.; Sharp, M.; Donald, D.; Lafreniere, M.; Braekevelt, E.; Strachan, M. J. Melting glaciers: A major source of persistent organochlorines to subalpine Bow Lake in Banff National Park, Canada. Ambio 2001, 30, 410-415.

(27) Li-guang, S.; Xue-bin, Y.; Can-ping, P.; Yu-hong, W. A 50-years record of dichloro-diphenyl-trichloroethanes and hexachlorocyclohexanes in lake sediments and penguin droppings on King George Island, Maritime Antarctic. J. Environ. Sci. 2005, 17, 899-905.

(28) Drewry, D. J.; Jordan, S. R.; Jankowski, E. J. Measured properties of the Antarctic ice sheet: surface configuration, ice thickness, volume and bedrock characteristics. Ann. Glaciol. 1982, 3, 83.

(29) Cook, A. J.; Fox, A. J.; Vaughan, D. G.; Ferrigno, J. G. Retreating glacier fronts on the Antarctic Peninsula over the past halfcentury. Science 2005, 308, 541-544.

(30) Jacobs, S. S.; Giulivi, C. F.; Mele, P. A. Freshening of the Ross Sea during the late 20th century. Science 2002, 297, 386-389.

(31) Oppenheimer, M. Global warming and the stability of the West Antarctic ice sheet. Nature 1998, 393, 325-332.

(32) Risebrough, R. W.; Peakall, D. B.; Herman, S. G.; Kirven, M. N. Polychlorinated byphenyls in the global ecosystem. Nature 1968, 220, 1098-1102.

(33) Inomata, O. N. K.; Montone, R. C.; Lara, W. H.; Weber, R. R.; Toledo, H. H. B. Tissue distribution of organochlorine residues - PCBs and pesticides - in Antarctic penguins. Antarctic Sci. 1996, 8 (3), 253-255.

\section{ES702919N}

